\title{
Common origin of all three coronary arteries from the right sinus of Valsalva - first case study accompanied by mitral valve prolapse and vein anomaly, second case study followed by successful percutaneous coronary intervention of right coronary artery stenosis
}

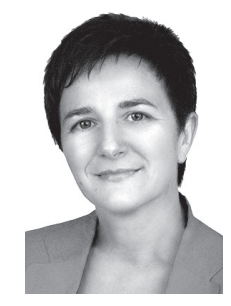

Brygida Przywara-Chowaniec ${ }^{1}$, Agata Puzio ${ }^{2}$, tukasz Czarnecki ${ }^{2}$, Damian Kawecki ${ }^{1}$, Jan Głowacki ${ }^{3}$, Ewa Nowalany-Kozielska ${ }^{1}$, Aleksandra Czarnecka ${ }^{4}$

${ }^{1}$ Second Department of Cardiology, School of Medicine with the Division of Dentistry in Zabrze, Medical University of Silesia in Katowice, Poland

2Department of Doctoral Studies, School of Medicine with the Division of Dentistry in Zabrze, Medical University of Silesia in Katowice, Poland

${ }^{3}$ Department of Diagnostic Imaging, Silesian Center for Heart Diseases, Zabrze, Poland

${ }^{4}$ Department of Doctoral Studies, University of Economics, Katowice, Poland

Kardiochirurgia i Torakochirurgia Polska 2017; 14 (1): 66-70

\begin{abstract}
Congenital anomalies of the coronary arteries can be divided into two broad categories: those that alter myocardial perfusion and those that do not. In coronary anomalies not altering myocardial perfusion, the coronary arteries originate from the aorta, but their origins are in unusual positions. Although myocardial perfusion is normal, the angiographer may have trouble locating them. Patients with an anomalous left main coronary artery arising from the right sinus of Valsalva are presented. The diagnosis was made by coronary angiography, transesophageal echocardiography and multislice computed tomography (MSCT). We present two cases: the first patient with coronary abnormalities had accompanying venous anomaly of lower extremities and mitral valve prolapse as well. The second patient had a history of anterior wall myocardial infarction and angioplasty with stent implantation. The extraordinary passage of the left coronary artery between the pulmonary trunk and sternum, undetectable in coronarography, was discovered due to MSCT.
\end{abstract}

Key words: coronary vessel anomalies, coronary angiography, multislice computed tomography.

\section{Introduction}

Congenital anomalies of the coronary arteries can be divided into two broad categories: those that alter myocardial perfusion and those that do not.

\section{Streszczenie}

Wrodzone anomalie tętnic wieńcowych można podzielić na dwie kategorie: zmieniające perfuzję mięśnia sercowego oraz niezmieniające. W anomaliach wieńcowych niezmieniających perfuzji mięśnia sercowego tętnice wieńcowe odchodzą od aorty, ale ich odejścia są w nietypowych lokalizacjach. Pomimo prawidłowej perfuzji mięśnia sercowego angiografista może mieć problem z ustaleniem ich położenia. W pracy przedstawiono przypadki pacjentów z nietypowym odejściem lewej tętnicy wieńcowej od prawej zatoki Valsalvy. Diagnoza zostata postawiona na podstawie koronarografii, echokardiografii przezprzełykowej i wielorzędowej tomografii komputerowej (MSCT). W pracy przedstawiono dwa przypadki: pierwszy pacjenta z anomalią tętnic wieńcowych i towarzyszącą anomalią naczyń żylnych kończyn dolnych oraz wypadaniem płatka zastawki mitralnej, u drugiego pacjenta wystąpił zawał ściany przedniej, leczony skutecznie angioplastyką z implantacją stentu. Nietypowy przebieg lewej tętnicy wieńcowej między pniem płucnym a mostkiem stwierdzono dzięki MSCT, co nie zostało wykryte w koronarografii.

Słowa kluczowe: anomalie naczyń wieńcowych, angiografia, wielorzędowa tomografia komputerowa.

In coronary anomalies not altering myocardial perfusion, the coronary arteries originate from the aorta, but their origins are in unusual positions. Although myocardial perfusion is normal, the angiographer may have trouble lo-

Address for correspondence: Brygida Przywara-Chowaniec MD, PhD, Second Department of Cardiology, 10 Curie-Skłodowskiej St, 41-800 Zabrze, Poland, phone: +48 603981 767, e-mail: bpzabrze@poczta.onet.pl

Received: 17.09.2015, accepted: 14.10.2016. 
cating them. These anomalies occur in about $0.5 \%$ to $1.0 \%$ of adult patients undergoing coronary angiography [1, 2].

Direct visualization of the proximal coronary arteries is also feasible.

With improved technology, especially the development of annular array and transesophageal 2D echocardiographic systems, the resolution required for visualizing the coronary arteries has been improved dramatically. The ultimate resolution value for examining the coronary arteries echocardiographically has yet to be determined. Researchers have indicated the usefulness of several different techniques including 2D, Doppler, color Doppler and transesophageal echocardiography in detecting congenital anomalies of the coronary arteries [3-5]. Recently, the tests that have been described in the literature as the new "gold standard" for diagnosing coronary anomalies are magnetic resonance angiography and multislice computed tomography (MSCT) $[6,7]$.

Anomalous origin of the left main coronary artery originating from the right or the anterior sinus of Valsalva has been associated with myocardial ischemia, myocardial infarction and sudden death [8-11].

There are a few descriptions of coronary anomalies already available in the medical literature: a case of separate origin of the left anterior descending (LAD) artery and the anomalous origin of the circumflex artery from the right sinus of Valsalva [12-14].

The origin of the left coronary artery from the right sinus of Valsalva can be dangerous during physical activity, whereas the narrowing of the coronary arteries associated with the angle of the origin of the coronary arteries and the pressure between the aorta and the path of right ventricular outflow can lead to sudden cardiac death. We present here two cases of very rare anomalous origin of coronary arteries. The first patient with coronary abnormalities had accompanying venous anomaly of lower extremities and mitral valve prolapse as well, but no atherosclerosis present. The patient was in the follow-up program for six years. The second patient had a history of anterior wall myocardial infarction (MI) and angioplasty with stent implantation. The extraordinary passage of the left coronary artery between the pulmonary trunk and sternum, undetectable in coronarography, was discovered due to MSCT.

\section{Case reports}

\section{First case}

A 38-year-old patient was admitted to the hospital with a year long history of substernal chest pain, exacerbated by stress and lasting about $10 \mathrm{~min}$. The patient also reported experiencing several syncope episodes, each lasting a few minutes, over the course of about one year. He also had an 18-year history of cigarette smoking of 20 cigarettes a day, except for the last 2 months, when he quit smoking. The patient also had a family history of coronary diseases. His brother and father had myocardial infarction at the age of 40 and 62 respectively and his mother was diagnosed with ischemic heart disease.
Physical examination revealed quiet systolic murmur in the mitral area, blood pressure (BP) $120 / 80 \mathrm{~mm} \mathrm{Hg}$, lungs clear by auscultation and huge superficial varicose veins of both lower extremities, especially on the left side.

Electrocardiogram showed regular sinus rhythm, approx. 62/min, significant Q wave in lead III, a low voltage $R$ wave in aVF, a flat and inverted T wave in lead III and a flat $T$ wave in lead aVF.

The exercise (treadmill) test with the Bruce protocol showed submaximal rhythm 157/min, achieved rhythm 160/min, and metabolic equivalent (MET) 11.5. The reason for stopping the submaximal rhythm was tiredness. Blood pressure before and after the test was respectively $95 / 60 \mathrm{~mm} \mathrm{Hg}$, and $130 / 70 \mathrm{~mm} \mathrm{Hg}$. The stress test was negative. 24-hour EKG with Holter method: heart rate (HR) 75/min; no arrhythmia or heart blocks were present.

Chest X-ray: except for small degenerative changes of cervical vertebra there were no pathological changes present.

Transthoracic echocardiography (Hewlett-Packard Sonos 2000) visualized normal size left ventricle with proper contractility both general and segmental, ejection fraction (EF) 55\%, mitral valve cusps with myxomatous changes and prolapse tendency with small mitral insufficiency.

Transesophageal echocardiography in short axis view visualized the left descending artery originating from the right coronary sinus and passing between the aorta and pulmonary artery.

Perfusion scintigraphy showed no significant ischemia of the heart in exertional recording, and slight hypokinesis of the apex area in resting recording.

The MSCT of the coronary arteries was performed. It revealed a strong right coronary artery. The left anterior descending artery also originates from the right sinus of Valsalva very close to the right coronary artery (RCA). It passes in an unusual way between the pulmonary trunk and sternum. The circumflex artery has its own origin at the right sinus of Valsalva, passes between the aorta and pulmonary trunk and is very weak. The system of RCA is dominating. There was no sign of coronary heart disease (Figs. 1 A, B).

However, it was decided to perform catheterization. It confirmed the MSCT diagnosis.

X-ray contrast coronary angiography: the LAD artery originates from the right coronary sinus and passes behind the aorta reaching the mid point of the anterior-lateral segment; the circumflex (CX) artery is a small artery and has a separate place of origin from the right coronary sinus; the RCA is a very big vessel supplying both of the inferior and posterior walls as well as the apex and part of the anterior wall. Hemodynamic study showed the coronary arteries without any stenosis. All of the coronary arteries originate from the right coronary sinus with the right coronary artery dominating (Figs. 2, 3).

Selective coronary angiography of the family members was performed. Both the father (the indication for the test was a typical cardiac chest pain) suggested therapy was coronary artery bypass graft (CABG) and the brother showed no coronary anomalies. 

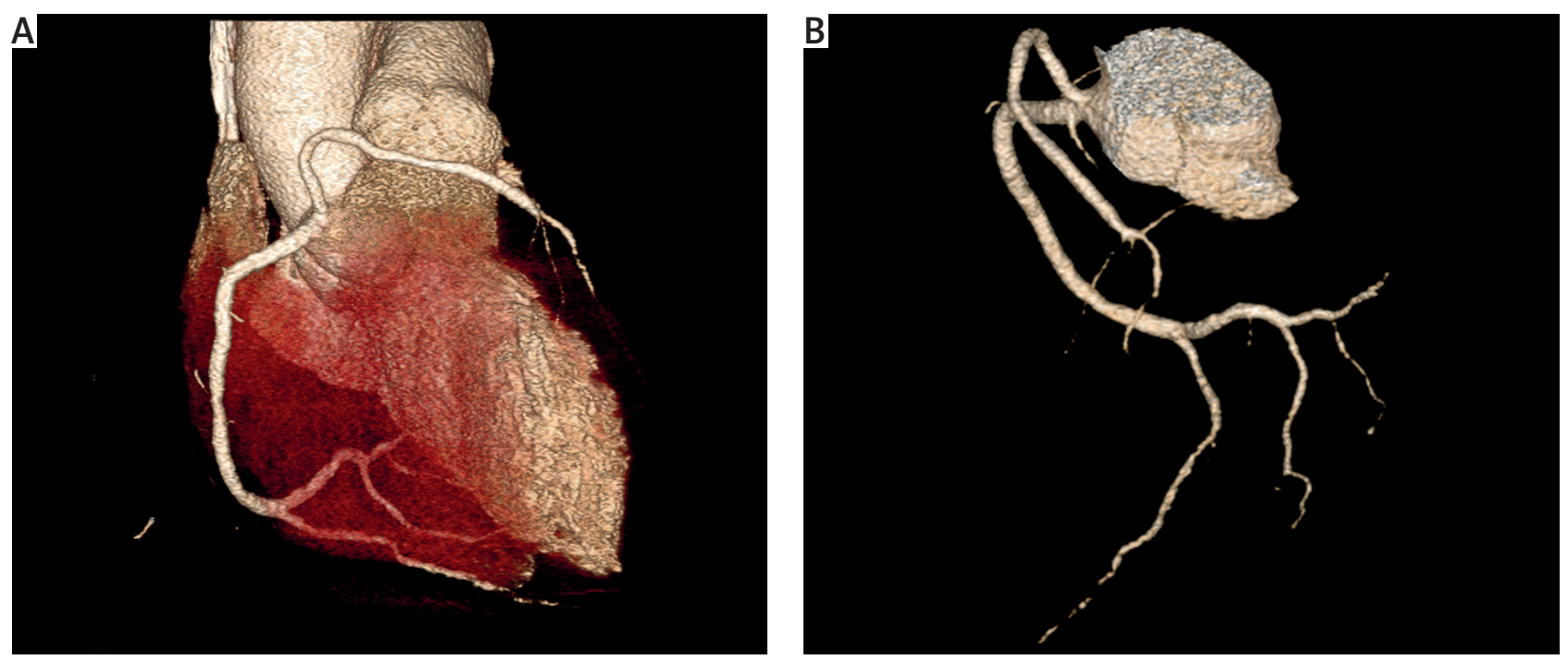

Fig. 1. Patient 1. A - Multislice computed tomography (MSCT) coronarography, volume rendering technique (VRT) view. Unusual passage of the left anterior descending (LAD) in front of pulmonary trunk (behind the sternum), B - MSCT coronarography, 3D reconstruction. Common origin of right coronary artery (RCA) and LAD from the right sinus of Valsalva

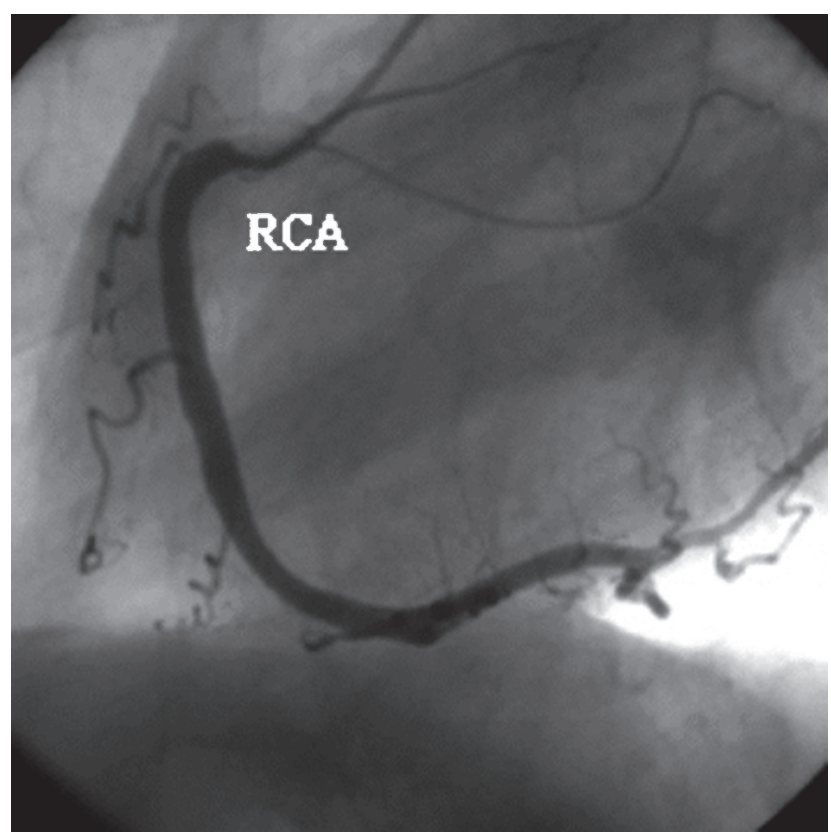

Fig. 2. Patient 1. Normal right coronary artery (RCA) left anterior oblique $60^{\circ}$ view

Peripheral vascular sonography:

- Right leg: Deep venous system without thrombosis and sufficient. Both of the superficial veins - the greater saphenous vein (GSV) and long saphenous vein (LSV) - are also sufficient. The posterior saphenous auxiliary vein is dilated, 13-15 $\mathrm{mm}$ in diameter without thrombosis. Perforating veins are sufficient as well. Antegrade venous flows show appropriate respiratory phases.

- Left leg: The deep venous system is sufficient. The GSV show no thrombosis. There is insufficiency of the common origin with the anterior saphenous auxiliary vein. The trunk is dilated $10 \mathrm{~mm}$ in diameter. The anterior saphenous auxiliary

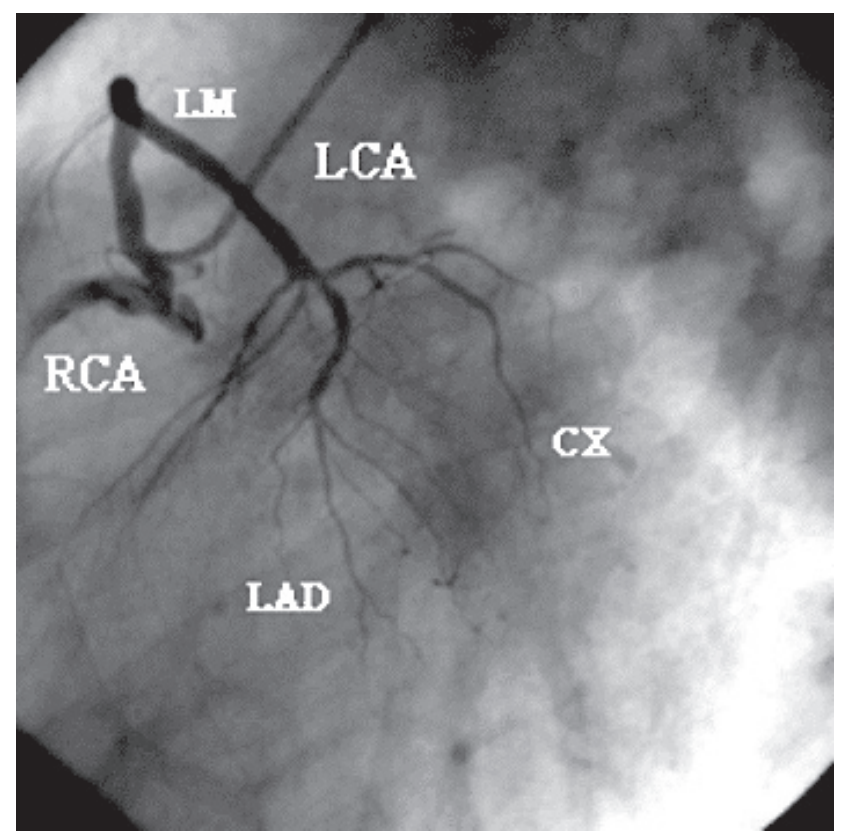

Fig. 3. Patient 1 . Left coronary artery origins from right coronary aortic bulb left anterior oblique $60^{\circ}$

RCA - right coronary artery, LAD - left anterior descending, LM - left main coronary artery, LCA - left coronary artery, CX - circumflex artery.

vein shows no thrombosis. The anterior surface of the thigh and calf show presence of the connecting vein conglomerations, 3-9 $\mathrm{mm}$ in diameter, without thrombosis. The GSV is sufficient. The perforating veins of the calf on the medial, posterior and lateral surface show medium degree dilatation with 4-5 mm diameter. Conclusion: Chronic, bilateral venous insufficiency especially on the left side (Fig. 4).

Cardiosurgical consultation: Suggested follow-up examination every 6 months.

Stress test: (5 years later) submaximal rhythm 154/min, achieved rhythm 130/min, exertion 8.5 MET; the reason for stopping the test was shortness of breath. 


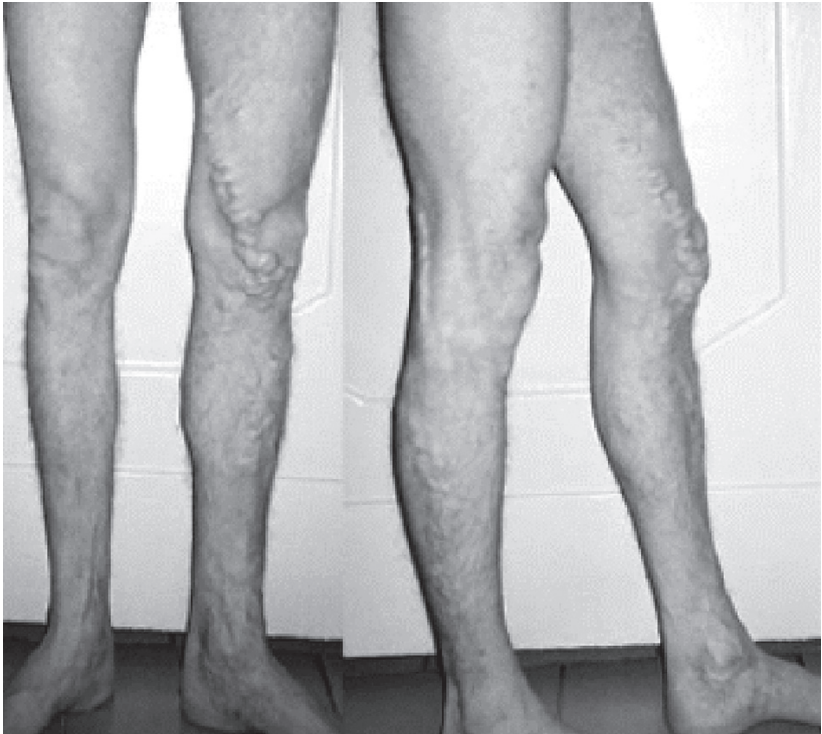

Fig. 4. Patient 1. Chronic, bilateral venous insufficiency

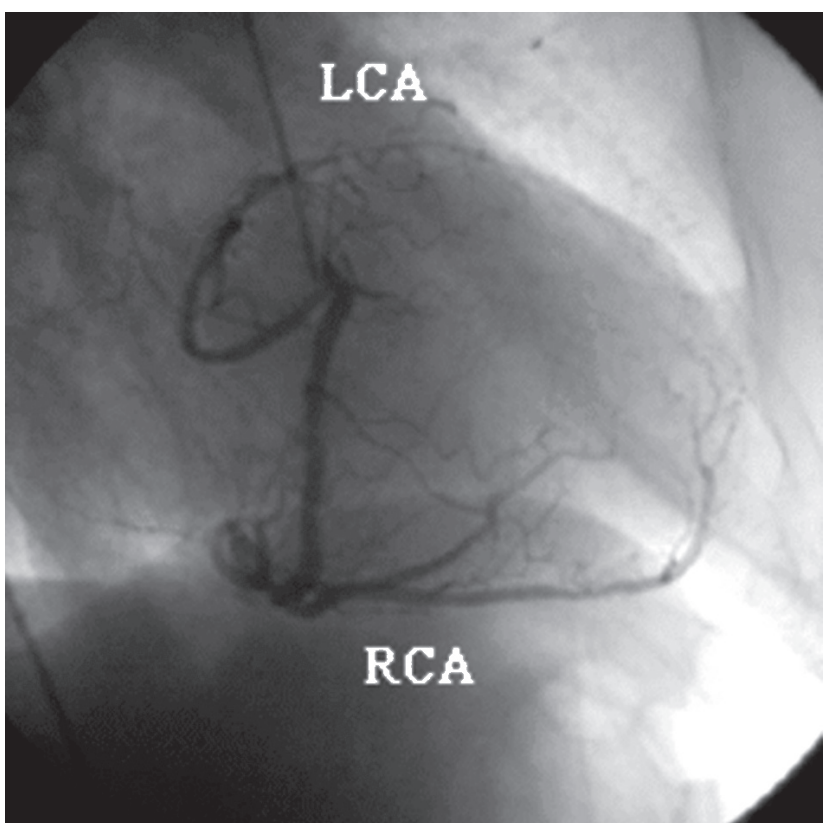

Fig. 6. Patient 2. Right (RCA) and left (LCA) coronary artery right anterior oblique (RAO) $60^{\circ}$ view

Follow-up echocardiography (same period as above): somewhat worse general contractility, EF 50\%, otherwise no changes compared to the original test.

The MSCT and X-ray coronary angiography show no atherosclerosis in coronary vessels.

\section{Second case}

A 68-year-old woman was referred to our Cardiological Department with unstable angina (positive troponin assay) after she suffered an anterior wall MI without a significant Q wave 3 weeks before. She had no history of cardiac pain until the recent $\mathrm{MI}$, but she had a long history of hypertension and 3 incidents of ischemic stroke (17, 10 and 2 years

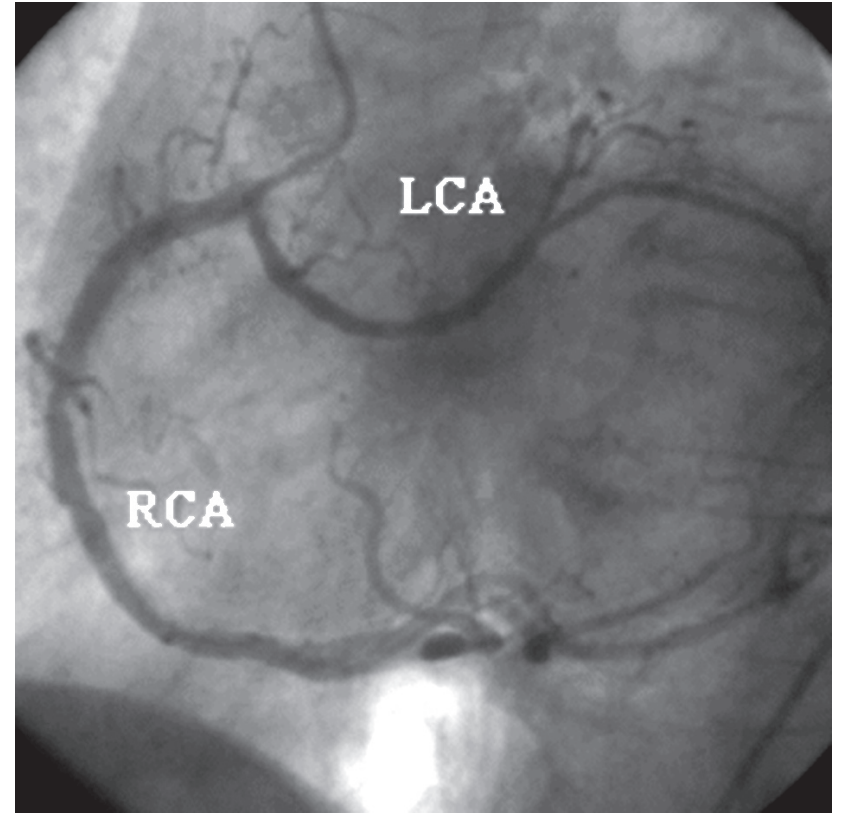

Fig. 5. Patient 2. Right (RCA) and left (LCA) coronary artery left anterior oblique $60^{\circ}$

ago). There was a significant family history - the patient's sister died from sudden cardiac death at the age of 70 .

The physical examination at the time of admission showed: BP 160/90 mm Hg, regular heart rate 60/min, lungs clear in auscultation, quiet systolic murmur in Erb point, bilateral varicose veins of both calves, more significant on the left side, and also obesity of medium degree with body mass index (BMI) $31 \mathrm{~kg} / \mathrm{m}^{2}$.

Additional tests revealed:

- EKG: regular sinus rhythm 60/min, left axis deviation, right bundle branch block, $T$ waves inverted in all chest leads.

- Echocardiography: end diastolic volume of left ventricle $80 \mathrm{ml}$, without segmental contractility disturbances, thickness of interventricular septum $1.4 \mathrm{~cm}$, posterior wall $1.2 \mathrm{~cm}$, left atrium area $18 \mathrm{~cm}^{2}$, right atrium area $16 \mathrm{~cm}^{2}$, right ventricle not enlarged $2.4 \mathrm{~cm}$, ascending aorta $3.5 \mathrm{~cm}$ in diameter, mitral valve shows minimal retrograde wave and thick, incrusted cusps, additionally the posterior mitral cusp has limited mobility without significant gradient, aortic valve shows punctuate calcifications, without gradient; the tricuspid and pulmonic valves are without organic changes.

- X-ray contrast coronary angiography revealed coronary artery anomalies with common origin of the left and right coronary arteries from the aortic bulb. The trunk showed no changes, both left descending and diagonal arteries closed, circumflex artery $(C X)$ regression of obtuse marginal $(\mathrm{OM})$, no changes, right circumflex artery greatly dominating, with critical narrowing in segment 2.

After pre-dilation of the right coronary artery with a 2.5/20 mm balloon, a 4.0/15 mm Chopin stent was implanted (Figs. 5, 6). 
Common origin of all three coronary arteries from the right sinus of Valsalva - first case study accompanied by mitral valve prolapse and vein anomaly, second case study followed by successful percutaneous coronary intervention of right coronary artery stenosis

\section{Discussion}

Congenital anomalies of the coronary arteries are usually of three categories: (1) origin of one or more coronary arteries from abnormal position in the coronary sinus, including origin of the left main coronary artery from the right aortic sinus; (2) origin of the coronary arteries from the pulmonary artery; (3) single coronary artery from the aorta.

Anomalous origin of the left coronary artery from the pulmonary artery accompanied by mitral valve prolapse and regurgitation were found in the literature $[15,16]$.

A 38-year-old patient was referred to our department presenting common origin of three coronary arteries from the right sinus of Valsalva accompanied by mitral valve prolapse and vein anomalies in lower extremities.

The atypical origin and unusual passage of the coronary arteries can be asymptomatic for many years. With time the addition of atherosclerotic complications exacerbates the symptoms and complicates the clinical picture. The choice of the revascularization method is difficult. The technical difficulties increase the risk of cardiosurgical revascularization and the angioplasty as well. Stent implantation seems to be the safer method for a patient with coronary anomalies, increasing the safety and reducing the frequency of restenosis.

\section{Disclosure}

Authors report no conflict of interest.

\section{References}

1. Click RL, Holmes DR Jr, Vlietstra RE Kosinski AS, Kronmal RA. Anomalous coronary arteries: location, degree of atherosclerosis and effect on survival - a report from the Coronary Artery Surgery Study. J Am Coll Cardiol 1989; 13: 531-537.
2. Page HL Jr, Engel HJ, Campbell WB, Thomas CS Jr. Anomalous origin of the left circumflex coronary artery. Recognition, angiographic demonstration and clinical significance. Circulation 1974; 50: 768-773.

3. Sanders SP, Parness IA, Colan SD. Recognition of abnormal connections of the coronary arteries with the use of Doppler color flow mapping. J Am Coll Cardiol 1989; 13: 922-926.

4. Shah RM, Nanda NC, Hsiung MC, Moos S, Roitman D. Identification of anomalous origin of the right coronary artery from pulmonary trunk by Doppler color flow mapping. Am J Cardiol 1986; 57: 366-367.

5. Vaksmann G, Mauran P, Rey C, Francart C, Dupuis C. Visualization of anomalous origin of the left main coronary artery from the pulmonary trunk by pulsed and color Doppler echocardiography. Am Heart J 1988; 116: 181-182.

6. Coronary artery anomalies in the adult. In: de Foyter PJ, Krestin GP (eds). Computed Tomography of the Coronary Arteries. Taylor and Francis, London 2005; 111-119.

7. Ropers D, Moshage W, Daniel WG, Jessl J, Gottwik M, Achenbach S. Visualization of coronary artery anomalies and their anatomic course by contrastenhanced electron beam tomography and three-dimentional reconstruction. Am J Cardiol 2001; 87: 193-197.

8. Baltaxe HA, Wixson D. The incidence of congenital anomalies of the coronary arteries in the adult population. Radiology 1977; 122: 47-52.

9. Roberts WC. Major anomalies of coronary arterial origin seen in adulthood. Am Heart J 1986; 111: 941-963.

10. Maron BJ, Epstein SE, Roberts WC. Causes of sudden death in competitive athletes. J Am Coll Cardiol 1986; 7: 204-214.

11. Cheitlin MD, De Castro CM, McAllister HA. Sudden death as a complication of anomalous left coronary origin from the anterior sinus of Valsalva: a notso-minor congenital anomaly. Circulation 1974; 50: 780-787.

12. Grodman RS, Vazzana TJ, Chu TN, Satyanarayana A, Bloomfield DA. Anomalous origin of the left coronary arteries from the right sinus of Valsalva with an unusual course. Cathet Cardiovasc Diagn 1997; 42: 437-439.

13. Chan CN, Berland J, Cribier A, Letac B. Angioplasty of the right coronary artery with the origin of the three coronary arteries from a single ostium in the right sinus of Valsalva. Am Heart J 1993; 126: 985-987.

14. Bystryk L, Nowosad H, Skalik R. Angioplastyka prawej tętnicy wieńcowej przy wspólnym odejściu trzech gałęzi tętniczych z prawej zatoki Valsalvy. Kardiol Pol 2000; 52: 479-481.

15. Harpaz D, Rozenman Y, Medalion B, Geva Y. Anomalous origin of the left coronary artery from the pulmonary artery accompanied by mitral valve prolapse and regurgitation: surgical implication of dobutamine stress echocardiography. J Am Soc Echocardiogr 2004; 17: 73-77.

16. Chau EM, Cheng LC, Lee JW. Severe mitral regurgitation due to mitral valve prolapse associated with Bland-White-Garland syndrome. Hong Kong Med J 2001; 7: 307-310. 